\title{
LOCATION PREFERENCES OF NEW PEDESTRIAN BRIDGES BASED ON MULTI-CRITERIA DECISION-MAKING AND GIS-BASED ESTIMATION
}

\author{
JURGIS ZAGORSKAS ${ }^{1 *}$, ZENONAS TURSKIS ${ }^{2}$ \\ ${ }^{1}$ Dept of Roads, Vilnius Gediminas Technical University, \\ Vilnius, Lithuania \\ ${ }^{2}$ Laboratory of Operational Research, Institute of Sustainable Construction, \\ Vilnius Gediminas Technical University, Vilnius, Lithuania
}

Received 9 April 2019; accepted 6 December 2019

\begin{abstract}
Non-motorized pedestrian and bicycle traffic is an effective and efficient tool for reducing the negative environmental impacts of transport and improving the quality of life in urban conditions. The strategies of creating new attractive spaces on the waterfront are prevalent amongst the municipalities in different countries. This kind of development intends the construction of new connection bridges, usually meant solely for walking and cycling. There are a significant number of studies covering the theme of pedestrian bridges, but the studies typically focus on technical parameters - serviceability, stress and vibrations, specifications for the design. Researchers and stakeholders rarely discuss displacement strategy, expenditure and future usability. This study aims to find out the best and the most useful bridge locations that would contribute to pedestrian network improvement, would add value to city image and give other benefits. A novel hybrid Multi-Criteria Decision-Making (MCDM) model,
\end{abstract}

* Corresponding author. E-mail: jurgis.zagorskas@vgtu.lt

Jurgis ZAGORSKAS (ORCID 0000-0001-7233-5932)

Zenonas TURSKIS (ORCID 0000-0002-5835-9388)

Copyright (C) 2020 The Author(s). Published by RTU Press

This is an Open Access article distributed under the terms of the Creative Commons Attribution License (http://creativecommons.org/licenses/by/4.0/), which permits unrestricted use,

distribution, and reproduction in any medium, provided the original author and source are credited. 
based on five different multi-criteria decision-making methods: Multiplicative Exponential Weighting (MEW), method of Evaluation Based on Distance from Average Solution (EDAS), an Additive Ratio Assessment (ARAS) method, expert judgement, and Step-Wise Weight Assessment Ratio Analysis (SWARA), is presented. A developed model allows solving complicated problems and finding a rationally, balanced solution. Arguments derived from this study help politicians and town planners as well as society.

Keywords: Multi-Criteria Decision-Making (MCDM), pedestrian accessibility, pedestrian bridges, riverside regeneration and development, road safety, space syntax, sustainable transportation.

\section{Introduction}

While the number of vehicles is rapidly growing, the urban and transportation professionals are attempting to change travel mode selection of people to less energy-intensive modes, particularly, walking and cycling. Non-motorized traffic planning becomes more prevalent in urban planning, and it becomes an essential part of transportation planning.

Walking and cycling contribute zero greenhouse gas emissions, contributes to reducing noise levels in an urban environment and help to reduce the space used by urban travellers. It also has substantial health benefits, despite the increased exposure to air pollution and traffic. More and more city governments are paying attention to walking and cycling route network planning, safety and adequate infrastructure.

The promotion of cycling in European cities is increasing. It is an efficient tool to reduce the negative environmental impacts of transport and to improve quality of life. Active transportation modes like bicycling is a critical element of sustainable transportation (Luo, Boriboonsomsin, \& Barth, 2020). In response to the benefits of bicycling to the environment and public health, the municipalities are working to establish new bicycle routes and to promote bicycle use for commuting trips.

In town planning theory and practice, there was always an aspiration to separate motorised and non-motorized traffic. Many cities have made progress on this path wholly or partially separating cycling network from vehicles. The general concept of how to achieve the separation lies in using the natural territories, e.g. green belts, green corridors, parks, for walking and cycling routes. Very often the river valleys represent a green corridor suitable for planning such routes. The research studies show that separating bicycle lanes from main motorised traffic volumes for health reasons is an essential and recognised strategy (Jack, Pantaleo, Smith, Yang, Thornburg, Kinney, \& Chillrud, 2018; 
Jereb, Batkovič, Herman, Šipek, Kovše, Gregorič, \& Močnik, 2018; Luo, Boriboonsomsin, \& Barth, 2020; Minet, Stokes, Scott, Xu, Weichenthal, \& Hatzopoulou, 2018). Many research papers (Gongora, Baquero, Franco, \& Mura, 2018; Gössling, Humpe, Litman, \& Metzler, 2019; Otero, Nieuwenhuijsen, \& Rojas-Rueda, 2018; Zalakeviciute, Buenaño, Sannino, \& Rybarczyk, 2018) stresses the importance of relocating urban bike lanes to the quieter streets, especially in the cities. The bicycle networks are quite often planned to be separated and moved away from heavy traffic to safer and healthier environments such as unused riversides, parks and natural territories.

The trend of moving the urban activities to the waterfront, revitalising riverside and using it for non-motorized access has created the vast need of constructing new pedestrian and bicycle bridges over the water canals or rivers. However, quite often, the need and future usability of the pedestrian bridge is considered only in the last place. The same applies to find the best location for the pedestrian bridge planners often decide positions of pedestrian bridges without a clear objective or use of scientific methods.

The design of rational construction requires focusing on the entire life cycle (Zavadskas, Turskis, \& Antucheviciene, 2015). Most of the multi-attribute decision-making methods use the following typical steps:

- define the relevant goals;

- determine the alternatives to evaluation;

- identify the appropriate attributes for assessing the choices;

- determine weights (relative importance) of the attributes;

- score all characteristics of each alternative;

- select a scoring method and calculate the multi-attribute utilities of various options;

- perform post-evaluation analysis.

\section{The aim and scope of this study}

Town planners usually decide the locations of pedestrian bridges and shown in the general plan of the town. These locations are discussed amongst politics and presented to society during the process of planning. Existing pathways or streets quite often determine locations for new bridges. A significant part of the construction of new pedestrian bridges from the year 2000 is built close to the existing bridge with car traffic. In such a case, it is possible to measure and weight pedestrian flow and the benefits of such a bridge. However, in some cases, the proposed locations are in green territories without yet established pathway network. These 
bridges are planned to represent the new image of the cities and provide new connections, travelling and recreational possibilities for citizens. In this case, the locations are very often decided by the author of the architectural contest without considering the necessity and usefulness of the planned bridge.

Town planning or transportation planning literature rarely address the question of finding the best locations for pedestrian bridges. Plan developers usually understood that the bridges are part of the transportation system and are meant to serve the travel demands. In practice, the bridge is planned in the place where there is a demand to cross the river. Other factors, like the terrain or lack of space due to the built-up territory, usually correct the location of the bridge. The pedestrian bridges are planned and built for more than only travelling. Bridges of this category are very often used to create the environment for relaxation, create new pathways with panoramic views to represent and advertise the cities in a new light. In any case, there is a need to evaluate the usefulness of the planned bridge to avoid redundant bridges in the future.

This study was meant to be a part of a comprehensive plan for sustainable transportation for Kaunas City (city size approximately 287000 inhabitants by the year 2018), Lithuania, Europe. The primary goal was to find out between many proposals made in the period from the year 2000 till the year 2020 the best and the most advantageous bridge locations serving both for pedestrian accessibility improvement and for adding value to the city image. The architectural contests in several places were already made without further consideration of usefulness or suitability of these bridges. Although it must have been done as a first step, it is essential to consider the priorities or even decline the construction of bridges in some locations. Before the contracts with operator companies are made, and construction works started, it is time to make final decisions on the priority and necessity of these bridges. Arguments derived from this study help politicians and town planners as well as society.

\section{Factors influencing the use of pedestrian bridges}

When deciding to construct a new pedestrian bridge, usually it is considered that this bridge serves as a connection and is used to a maximum possible capacity. Nevertheless, in many cases, there is a lack of arguments and clear objectives in the initial stage, just before the construction of the bridge takes place. Quite often the results are unused bridges, empty riverside and waste of investment funds.
Location Preferences

of New Pedestrian

Bridges Based

on Multi-Criteria

Decision-Making

and GIS-Based

Estimation 
There are quite a few studies, examining the factors influencing the use of pedestrian bridges. Some studies show that the main reasons for the usage of the pedestrian bridge are perceived safety and psychological comfort when walking away from heavy traffic. The studies also report the main reasons for the appearance of redundant pedestrian bridges. Main reasons are inconvenient to access to the bridge, i.e. too many stairs, significant distances in open windy space and loss of time when the pedestrian bridge is in a worse location than the existing bridge.

Authors of few studies conclude that for increasing the pedestrian bridge use, escalators and fences seem to be a right solution in addition to the education of pedestrians and safety of bridges (Mohtasham-Amiri, Barge_Gol, Jafari-Shakib, \& Abedian, 2018). However, these measures are at most the correction of errors made in the initial stage of placing the bridge at right location and position.

Existing traffic flows in surroundings help to predict volumes of future pedestrian and cyclist traffic flow on the bridge. Precast is made using traffic flow data or Global System for Mobile communications (GSM) device data, which is available from several online resources (i.e. https://www.strava.com/). Also, traffic flows are modelled, taking into account displacement of living places, working places and main attraction objects in town. This study uses both methods. The aggregated value of communication flows, recreational flows, and the collected data derived from GSM devices represent the total predicted traffic volume on bridges. This number describes the usefulness of the pedestrian bridge.

\section{Perceived benefits from adding new pedestrian bridges to existing town structure}

There are many widely accepted benefits from adding new pedestrian bridges to society and the quality of the urban environment. Most obvious positive effects are of improving the connectivity and adding a new value to the city image. Researchers recognise many advantages of pedestrian bridges and focus on several fields considering different groups of factors. The most recognised and discussed between academia, politicians and society themes fall into the six groups:

1. Connectivity. Adding new bridge always improves the connectivity of the overall transportation network. With the construction of a new bridge, there is still improvement in connectivity between two river banks. It can be measured in reduced distances or travel time, travel costs between objects. Indirectly it is possible to evaluate the benefits with the spatial syntax methods used to define the 
centrality of network elements (Marshall, Gil, Kropf, Tomko, \& Figueiredo, 2018; Parthasarathi \& Levinson, 2018). A number of researches conducted on the theme of walking and space syntax demonstrate that the position of the bridge - the element of the street network - is the primary factor influencing pedestrian movement (Cooper, 2018; Koohsari, Oka, Owen, \& Sugiyama, 2019; Pafka, Dovey, \& Aschwanden, 2018; Suzuki, 2018). The space syntax characteristics of integration and connectivity measures positively influence pedestrian movement with the choice being the most reliable predictor (Sharmin \& Kamruzzaman, 2018).

2. Usage. The pedestrian bridge is successful when, after construction, it becomes the favourite walking link or destination. There is always a need to predict the quantities of future pedestrian and cyclist movement on the proposed bridge. The prediction of pedestrian behaviour is becoming an increasingly popular research field (Ridel, Rehder, Lauer, Stiller, \& Wolf, 2018). It is assessed using different general and more sophisticated methods known in traffic planning theory (Fang, Li, Yu, Guo, \& Ma, 2019; Hartmann, Ferrara, \& Watzenig, 2018; Hartmann, Stolz, \& Watzenig, 2018; Particke, Hiller, Feist, \& Thielecke, 2018; Wu, Ruenz, \& Althoff, 2018). The pedestrian movement, however, is less predictive than motorised traffic. Pedestrian movement generally is divided into two modes by the purpose - walking for transport and walking as a relaxation activity (or practical and recreational uses) (Kajosaari, Hasanzadeh, \& Kyttä, 2019; Li, Chi, \& Jackson, 2018). Both purposes generate similar traffic quantities, but the prediction methods differ. The total predicted traffic must consider both categories of the walk.

3. Image. The reasons of built pedestrian bridges often are creating a more appealing cities vision, making cities more attractive and desirable places to live (Jin, 2018; Nowacka-Rejzner, 2019; Sender \& Maslanko, 2018; Vert, Nieuwenhuijsen, Gascon, Grellier, Fleming, White, \& Rojas-Rueda, 2019). This issue is very often addressed by politicians who have a significant influence on the initial preconstructional level. Also, architects stress it as vital to the local community.

4. Health. The promotion of physical activity through better urban design is one pathway to achieve health and well-being improvements (Vert, Nieuwenhuijsen, Gascon, Grellier, Fleming, White, \& Rojas-Rueda, 2019). Pedestrian bridge significantly contributes to making urban environment more walkable and cycle-able; it invites people to for more physical activity. Also, health benefits from the construction of new pedestrian bridges 
occur from moving pedestrian and cycling paths away from toxic fumes produced by vehicles (Qiu, Song, Hao, Li, \& Gao, 2018; Seltenrich, 2018; Shekarrizfard, Valois, Weichenthal, Goldberg, Fallah-Shorshani, Cavellin, \& Hatzopoulou, 2018).

5. Road Safety. Safety benefits occur from minimising the contact and reducing the exposure time of pedestrians to traffic lanes (Congiu, Sotgiu, Castiglia, Azara, Piana, Saderi, \& Dettori, 2019). Wherever the new bridge serves to remove the walking and cycling activities from existing bridges loaded by motorised traffic, it is considered as a road safety improvement.

6. Cost-Effectiveness. The last and quite complex factor is the cost of construction and overall cost of building a pedestrian bridge. Today, bridge design seeks not only to minimise costs, but also to minimise adverse environmental impacts (García-Segura, PenadésPlà, \& Yepes, 2018; Pellegrini, Ribó, Jordan, \& Sobrino, 2017). Broadly the cost in most part depends on the width of the river or river valley. Also, it significantly depends on terrain and ground or soil conditions. Construction cost consists of costs for building a foundation, bearing constructions, facing, building the connections to the bridge (Oliveira, Figueiredo, Vicente, \& Almeida, 2018). There are also sub-factors, like finding the best operator or company for construction works and maintenance. Maintenance of the bridge is also the part of the cost and consists of cleaning, removing the snow, renewing the outlook of the bridge, periodical change of the bearing construction parts (Andersson, Silfwerbrand, Selander, \& Trägårdh, 2018; Balogun, Tomor, Lamond, Gouda, \& Booth, 2019; Fujino, 2018; Xie, Wu, \& Wang, 2018).

\section{Materials and methods}

Making contemporary road building and bridge construction decisions are usually a complicated and complex process. Many parties are involved in this process from the initial stage to implementation. The actors and decision-makers are a society in general, politics, town planners, architects, engineers and at the last stage construction companies. Different issues are given priority and importance in every stage. The effects vary depending on the expert or public opinion. However, the description of the problems usually is substituted to multiple quantitative and qualitative criteria (Sivilevičius, Zavadskas, \& Turskis, 2008; Šaparauskas, Zavadskas, \& Turskis, 2011; Zavadskas, Govindan, Antucheviciene, \& Turskis, 2016). One of rational and environment-friendly choice description is to say that all the parts of the objects are well balanced (Zolfani, Zavadskas, \& Turskis, 2013). 
Complications and complexity of bridge construction decisions occur from in previous research discussed the nature of such arrangements:

- The decisions must be economical, environmentally friendly, and include social factors (Hashemi, Mousavi, Zavadskas, Chalekaee, \& Turskis, 2018; Štreimikienè, Šliogerienè, \& Turskis, 2016);

- Managers always make decisions in a dynamically changing environment (Zavadskas, Kaklauskas, Turskis, \& Kalibatas, 2009; Zavadskas, Turskis, \& Bagočius, 2015).

To evaluate and compare the alternative bridge locations MultiCriteria Decision-Making Methods (MCDM) is the most prominent, scientifically based and correct solution (Zavadskas, Liias, \& Turskis, 2008). It allows comparing different pedestrian bridge location alternatives and making priority line or deciding to decline the choice.

There exist varieties of multiple criteria decision-making methods. Selecting of appropriate decision method depends on the aim of the problem, available information, the complexity of the problem and qualification of persons who are making decisions. A more comprehensive overview of multiple criteria decision-making methods, classification and applications are presented by Zavadskas \& Turskis (2010). Multi-Criteria Decision-Making methods, in some situations, give a different ranking of feasible alternatives. Therefore, hybrid techniques are useful in such cases (Turskis \& Juodagalvienè, 2016). In this research five methods are integrated into the solution model: Additive Ratio Assessment (ARAS), Evaluation Based on Distance from Average Solution (EDAS) (Keshavarz Ghorabaee, Zavadskas, Olfat, \& Turskis, 2015), Multiplicative Exponential Weighting (MEW), expert judgement, and Step-Wise Weight Assessment Ratio Analysis (SWARA).

In the MCDM of the discrete optimisation problem, any problem represented by the decision-making matrix (DMM) of preferences for $m$ feasible alternatives (rows) rated on $n$ criteria (columns):

$$
X=\left[\begin{array}{ccccc}
x_{01} & \cdots & x_{0 j} & \cdots & x_{0 n} \\
\vdots & \ddots & \vdots & \ddots & \vdots \\
x_{i 1} & \cdots & x_{i j} & \cdots & x_{i n} \\
\vdots & \ddots & \vdots & \ddots & \vdots \\
x_{m 1} & \cdots & x_{m j} & \cdots & x_{m n}
\end{array}\right] ; \quad i=\overline{0, m} ; j=\overline{1, n}
$$

where $m$ - the number of alternatives, $n$ - the number of criteria describing each alternative, $x_{i j}$ - a value representing the performance value of the $\underline{i}$ alternative in terms of the $j$ criterion, $x_{0 j}$ - optimal value of $j$ criterion.
Location Preferences

of New Pedestrian

Bridges Based

on Multi-Criteria

Decision-Making and GIS-Based

Estimation 
Table 1. The criteria selected by experts for the evaluation of alternative pedestrian bridge locations

\begin{tabular}{|c|c|c|c|}
\hline Criteria & $\begin{array}{l}\text { Sub-criteria } \\
\text { and their part } \\
\text { in total criteria } \\
\text { value }\end{array}$ & Description & Explanation of measurement \\
\hline \multirow[t]{2}{*}{ Connectivity } & $\begin{array}{l}\text { Integration } \\
(50 \%)\end{array}$ & Space syntax - integration & \multirow{2}{*}{$\begin{array}{l}\text { The number derived from space } \\
\text { syntax application DepthMapX } \\
\text { (otp.spacesyntax.net/ } \\
\text { software-and-manuals/ } \\
\text { depthmap/ } \\
\text { www.spacesyntax.net/ } \\
\text { software/) }\end{array}$} \\
\hline & $\begin{array}{l}\text { Connectivity } \\
(50 \%)\end{array}$ & Space syntax - connectivity & \\
\hline \multirow[t]{2}{*}{ Usage } & $\begin{array}{l}\text { Volume, } \\
\text { transportation } \\
(60 \%)\end{array}$ & $\begin{array}{l}\text { Predicted traffic volume } \\
\text { from walking and cycling } \\
\text { for transportation (shortest } \\
\text { distance estimations is } \\
\text { the basis for predicting) }\end{array}$ & $\begin{array}{l}\text { Min and Max numbers } \\
\text { of the expected amount } \\
\text { for transportation journeys }\end{array}$ \\
\hline & $\begin{array}{l}\text { Volume, } \\
\text { recreation } \\
(40 \%)\end{array}$ & $\begin{array}{l}\text { Predicted traffic volume } \\
\text { from walking and cycling } \\
\text { for recreation } \\
\text { (the attractiveness } \\
\text { of the place, psychological } \\
\text { comfort, and other } \\
\text { is the basis for prediction) }\end{array}$ & $\begin{array}{l}\text { Min and Max numbers } \\
\text { of the predicted amount } \\
\text { for relaxing walks or bicycle } \\
\text { rides }\end{array}$ \\
\hline \multirow[t]{2}{*}{ Image } & Views (50\%) & $\begin{array}{l}\text { Estimation of imagery } \\
\text { and absence of scenic views } \\
\text { or panoramic views of the city }\end{array}$ & $\begin{array}{l}\text { Expert evaluation in } 5 \text { points } \\
\text { scale ( } 5 \text { being the highest } \\
\text { value) }\end{array}$ \\
\hline & Visibility (50\%) & $\begin{array}{l}\text { Visibility of the bridge } \\
\text { from main urban centres, } \\
\text { transportation channels } \\
\text { and central objects }\end{array}$ & $\begin{array}{l}\text { Expert estimation in } 5 \text { points } \\
\text { scale ( } 5 \text { being the highest } \\
\text { value) }\end{array}$ \\
\hline \multirow[t]{2}{*}{ Health } & $\begin{array}{l}\text { Sports } \\
\text { activities } \\
(50 \%)\end{array}$ & $\begin{array}{l}\text { The possibilities to use } \\
\text { the bridge for increased } \\
\text { physical activity }\end{array}$ & $\begin{array}{l}\text { Evaluation in } 5 \text { points scale } \\
\text { ( } 5 \text { being the highest value) } \\
\text { assessing the adjacent } \\
\text { riverside walks bicycle paths, } \\
\text { sporting facilities }\end{array}$ \\
\hline & $\begin{array}{l}\mathrm{NO}_{2}, \mathrm{SO}_{2}, \mathrm{CO}, \\
\mathrm{PM}_{10}, \mathrm{PM}_{2.5} \\
\text { concentration } \\
(50 \%)\end{array}$ & $\begin{array}{l}\text { Sum of toxic fumes } \\
\text { and particles, in accordance } \\
\text { to exposure norms, multiplied } \\
\text { by pedestrian movement } \\
\text { volume from nearest bridges } \\
\text { where it is planned to change }\end{array}$ & $\begin{array}{l}\text { Estimation in } 5 \text { points scale } \\
\text { ( } 5 \text { being the highest value, } \\
0 \text { - the bridge does not } \\
\text { contribute to reducing } \\
\text { of pedestrian movement } \\
\text { on nearest bridges) }\end{array}$ \\
\hline
\end{tabular}




\begin{tabular}{|c|c|c|c|}
\hline Criteria & $\begin{array}{l}\text { Sub-criteria } \\
\text { and their part } \\
\text { in total criteria } \\
\text { value }\end{array}$ & Description & Explanation of measurement \\
\hline Road Safety & Road safety & $\begin{array}{l}\text { Estimation of minimising } \\
\text { the contact and reducing } \\
\text { the exposure time } \\
\text { of pedestrians to heavy } \\
\text { traffic lanes on nearest } \\
\text { bridges }\end{array}$ & $\begin{array}{l}\text { Estimation in } 5 \text { points scale } \\
\text { ( } 5 \text { being the highest value, } \\
0 \text { - the bridge does not } \\
\text { contribute to reducing } \\
\text { of pedestrian movement } \\
\text { on nearest bridges) }\end{array}$ \\
\hline \multirow[t]{2}{*}{$\begin{array}{l}\text { Cost- } \\
\text { Effectiveness }\end{array}$} & $\begin{array}{l}\text { General cost } \\
\text { (sum) }\end{array}$ & $\begin{array}{l}\text { The approximate crude cost } \\
\text { dependent on the length } \\
\text { of the bridge }\end{array}$ & \multirow{2}{*}{$\begin{array}{l}\text { The cost estimated conforming } \\
\text { to Arraes, Deyglun, Gardner, } \\
\text { Osarczuk, \& Rajkarnikar } \\
\text { (2015), Bushell, Poole, Zegeer, } \\
\text { \& Rodriguez (2013), Jia, } \\
\text { Ibrahim, Hadi, Orabi, Ali, \& } \\
\text { Xiao (2016), and internet } \\
\text { sources http://www. } \\
\text { excelbridge.com/for-engineers/ } \\
\text { pedestrian-walkway-bridges }\end{array}$} \\
\hline & $\begin{array}{l}\text { Surroundings } \\
\text { (sum) }\end{array}$ & $\begin{array}{l}\text { The crude estimation } \\
\text { of pavements needed } \\
\text { to connect the bridge } \\
\text { to existing pathways }\end{array}$ & \\
\hline
\end{tabular}

Turskis \& Juodagalvienė (2016) integrated different criteria values to one optimality criterion performed by applying ten different MCDM methods (Zavadskas, Turskis, \& Kildienè, 2014), namely:

- Simple Additive Weighting (SAW) (Antuchevičienè, Zavadskas, \& Turskis, 2015);

- Additive Ratio Assessment (ARAS) method (Zavadskas \& Turskis, 2010);

- The method of Evaluation Based on Distance from Average Solution (EDAS) (Keshavarz Ghorabaee, Zavadskas, Olfat, \& Turskis, 2015);

- Multiplicative Exponential Weighting (MEW) (Antuchevičienè, Zavadskas, \& Turskis, 2015);

Establishing the criteria system for evaluation of the usefulness of the new pedestrian bridge at the planned location

The expert group formed to develop the system of criteria and to calculate criteria weights, and the experts were selected mainly from urban planners, transportation planners and architects. Also, there were experts from municipality administration, transportation and strategic planning departments. The attempt was made to select the experts interested in planning Kaunas City, and with knowledge of the city needs, therefore local experts were dominating. In this case, local experts partially reflected the opinion of the local community 
and society, and consequently, the study, in some part incorporates the publicity principle.

The criteria system proposed by experts has six general groups and 11 sub-criteria presented in Table 1 . This system of criteria is only used to select between the alternative pedestrian bridge locations or decide whether to decline the proposed placement of the bridge.

\section{Criteria weights determination}

There are various approaches for assessing weights, e.g. the eigenvector method, SWARA (Keršulienė, Zavadskas, \& Turskis, 2010), expert way, Eckenrode rating technique (Turskis, Dzitac, Stankiuvienė, \& Šukys, 2019), Analytic Hierarchy Process (AHP) (Saaty, 1977, 1990), and Entropy method.

First of all, each of the experts ranked criteria. To the most significant criterion is given rank 1, and to the least significant one is given grade 8. The average value of grades determines the overall positions of the group of experts.

Later, SWARA method is applied to determine fuzzy group weight weights of criteria. Keršulienè, Zavadskas, \& Turskis (2010) developed the SWARA methodology and used it for the selection of analytical dispute resolution method. The Step-Wise Ratio Assessment method provides a rational framework to help experts differentiate in quantitative terms the relative importance of the specified criteria.

The Step-Wise Ratio Assessment method was used to solve complicated multi-criteria decision-making problems when there exists

Table 2. Ranks of the criteria based on the estimation of ten selected experts

\begin{tabular}{|c|c|c|c|c|c|c|c|c|c|c|c|c|c|}
\hline \multirow{2}{*}{$\begin{array}{l}\text { Criteria } \\
\text { group* }\end{array}$} & \multicolumn{10}{|c|}{$\begin{array}{l}\text { Expert evaluation of criteria weight } \\
\qquad 10 \text { experts }\end{array}$} & \multirow{2}{*}{$\begin{array}{l}\text { W } \\
\text { हे } \\
\text { ज } \\
47\end{array}$} & \multirow{2}{*}{ 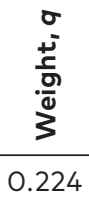 } & \multirow{2}{*}{$\begin{array}{l}\frac{y}{c} \\
\frac{y}{\alpha} \\
6\end{array}$} \\
\hline & 5 & 5 & 4 & 5 & 3 & 6 & 2 & 6 & 5 & 6 & & & \\
\hline Road Safety & 3 & 4 & 1 & 6 & 4 & 4 & 3 & 5 & 6 & 5 & 41 & 0.195 & 5 \\
\hline Image & 6 & 6 & 5 & 4 & 2 & 3 & 1 & 3 & 2 & 2 & 34 & 0.162 & 4 \\
\hline Cost-Effectiveness & 4 & 3 & 6 & 1 & 1 & 2 & 4 & 4 & 4 & 3 & 32 & 0.152 & 3 \\
\hline Connectivity & 1 & 2 & 3 & 2 & 6 & 5 & 5 & 1 & 1 & 4 & 30 & 0.143 & 2 \\
\hline \multirow[t]{2}{*}{ Usage } & 2 & 1 & 2 & 3 & 5 & 1 & 6 & 2 & 3 & 1 & 26 & 0.124 & 1 \\
\hline & & & & & & & & & & $\Sigma$ & 210 & & \\
\hline
\end{tabular}


Table 3. Criteria describing alternatives and their weights determined by applying Step-Wise Weight Assessment Ratio Analysis

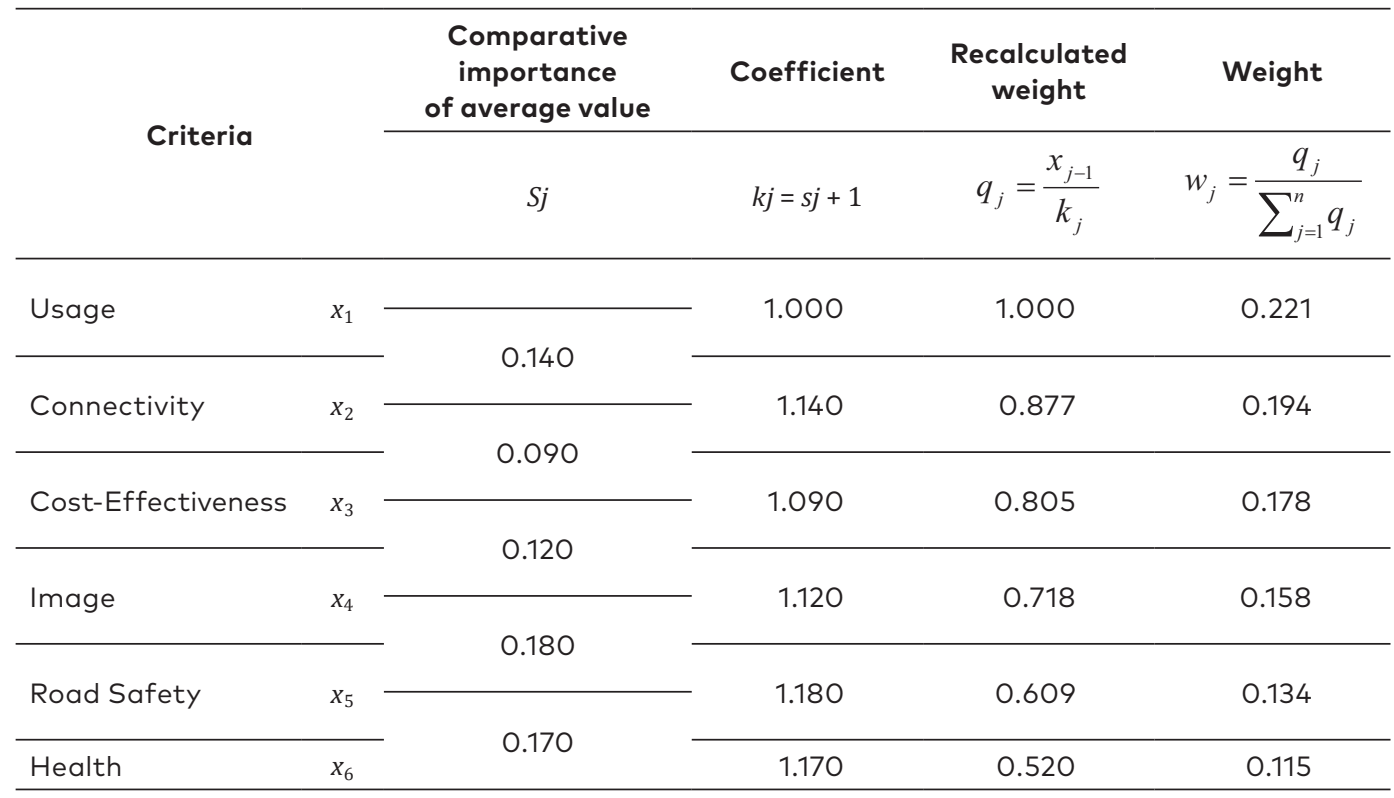

a need to find the reliable and rational solution (Juodagalvienè, Turskis, Šaparauskas, \& Endriukaitytė, 2017; Ruzgys, Volvačiovas, Ignatavičius, \& Turskis, 2014; Zavadskas, Antucheviciene, Adeli, \& Turskis, 2016; Zavadskas, Mardani, Turskis, Jusoh, \& Nor, 2016; Zolfani, Zavadskas, \& Turskis, 2013) used this method to solve construction problems.

First of all, the experts ranked the criteria conforming to their importance. For the most critical criterion value equal to 1 was assigned, and to the least essential one - value 6. Table 2 shows the criteria ranking procedure and finally ranked criteria conforming to their importance.

Default value one is assigned to the top-ranked criterion. The expert gives a value less than 1 to the secondly ranked criterion (or equal to 1 in case he thinks the two first criteria are of the same importance). The expert continues assigning a less (or equal) value to the next most crucial criterion until all criteria are assessed by a numerical value denoting their relative importance.

At the next step, weights are given to each criterion. The difference among importance (Table 3) provided according to the consensus of estimations of experts.

The normalised criteria weights resulting from values of experts present the calculation results.

At the second stage, SWARA method was applied. 


\section{Description of the alternatives}

The proposed locations for pedestrian bridges taken from General Plan of Kaunas City, which includes information selected from many studies and programs. Only two pedestrian bridges over the river Nemunas exist today; other bridges are automobile bridges with the possibility to walk. Cycling on these bridges has some limitations. The width of the river is from $180 \mathrm{~m}$ to $240 \mathrm{~m}$, and the bridge construction is quite expensive for a municipality of 287000 citizens.

The Figure shows the proposed locations.

Number 1 is the most expensive and constructively challenging - the bridge at this place has to cover $240 \mathrm{~m}$ of the 1.5-5.0-meter-deep river with massive river ice jams in spring. This location offers spectacular views over Kaunas Old Town and surroundings but would be useful more for the automobile connections.

Location 2 is the least costly - the bridge lies on the shallow river Neris (0.5-2.5 m) with a few times less water debit than Nemunas

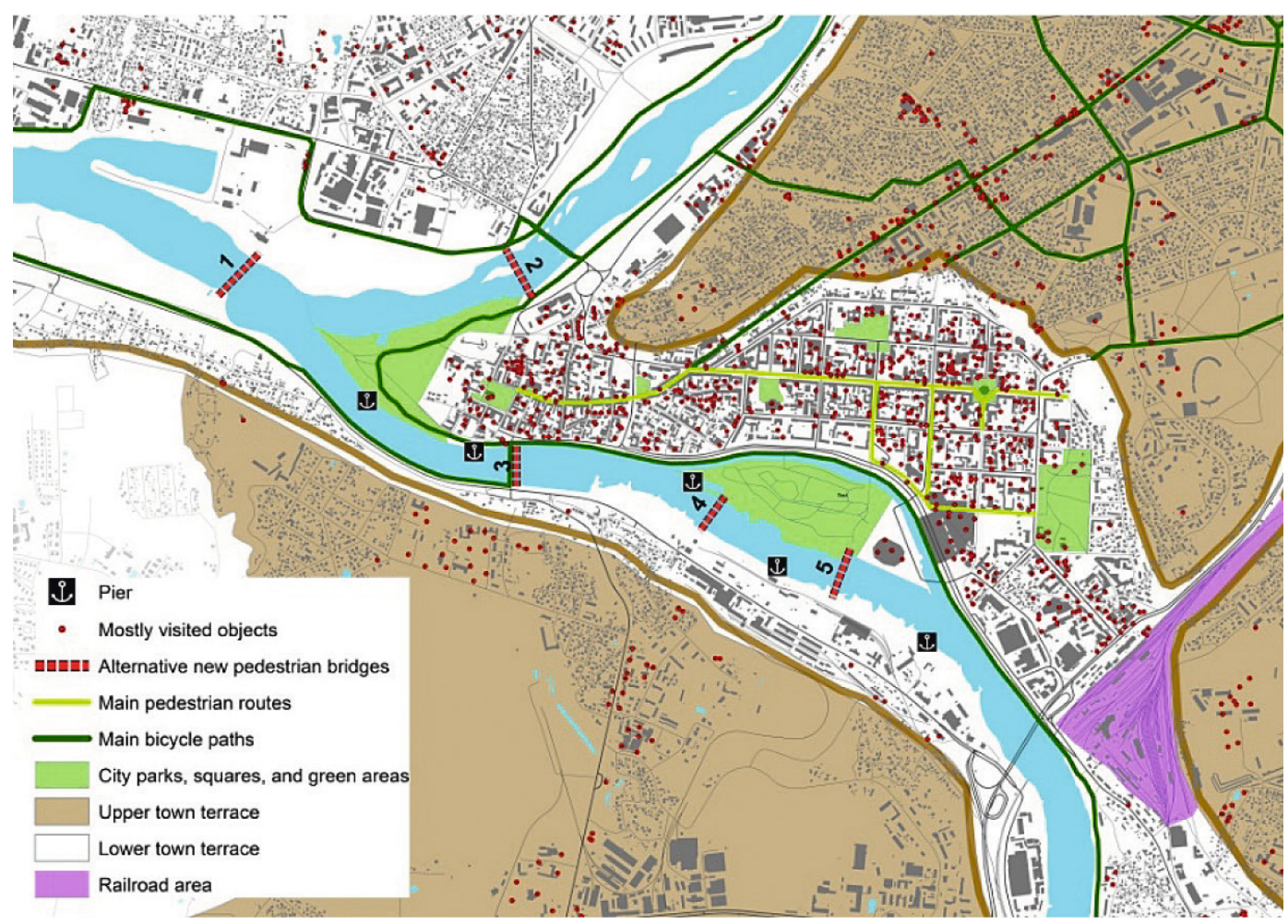

Figure. Proposed locations for pedestrian bridges in Kaunas city, Lithuania 
river. From this bridge, both pedestrian and cyclists would benefit. Estimations show that it would be used at most from all other locations.

Location 3 would add comfort for walking and cycling. The existing bridge is mostly occupied by cars and is quite problematic for access and crossing by bicycle.

Locations 4 and 5 are similar and connect Nemunas island city park with another bank of the river Nemunas. However, both these bridges do not connect living districts or commercial objects and would be used mostly for recreational purposes. These bridges are also less visible from tourist and main attraction places in town.

The criteria values for Image, Road safety and Health were given by local experts, with additional information about the average level of pollutants at proposed locations.

Other criteria values were also derived with the help of experts but were based mostly on numbers. Connectivity, Usage and CostEffectiveness were calculated and then given to experts to admit and make corrections. Table 4 presents the estimated values.

Table 4. Estimated criteria values for alternative bridge locations

\begin{tabular}{|c|c|c|c|c|c|c|}
\hline $\begin{array}{l}\frac{1}{0} \\
\frac{0}{\varepsilon} \\
\frac{2}{2} \\
z\end{array}$ & 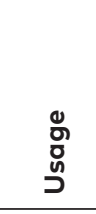 & 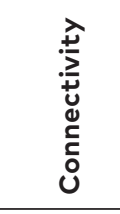 & & 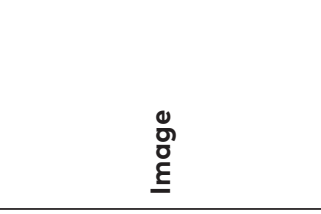 & \begin{tabular}{l}
$\lambda$ \\
\multirow{2}{*}{} \\
4 \\
0 \\
0 \\
0 \\
0 \\
0 \\
0 \\
$\alpha$
\end{tabular} & $\begin{array}{l}\frac{5}{ \pm} \\
\frac{ \pm}{0} \\
\frac{0}{1}\end{array}$ \\
\hline & $x_{1}$ & $x_{2}$ & $x_{3}$ & $x_{4}$ & $x_{5}$ & $x_{6}$ \\
\hline 1 & 1250 & 3.0720 & 1044172 & $\begin{array}{l}10 \\
\text { (adds most } \\
\text { to the representation } \\
\text { of the city) }\end{array}$ & 5 & 1918.55 \\
\hline 2 & 2260 & 3.9285 & 482990 & 8 & 7 & $\begin{array}{c}4030.82 \\
\text { (the most health } \\
\text { benefiting) }\end{array}$ \\
\hline 3 & 1870 & 4.0457 & 762163 & 9 & $\begin{array}{c}9 \\
\text { (adds most } \\
\text { to road safety) }\end{array}$ & 3153.95 \\
\hline 4 & 590 & 4.0299 & 902810 & 7 & $\begin{array}{c}1 \\
\text { (adds least } \\
\text { to road safety) }\end{array}$ & 1056.01 \\
\hline 5 & 360 & 3.3064 & 720965 & $\begin{array}{c}6 \\
\text { (adds least to image } \\
\text { of the city) }\end{array}$ & 2 & $\begin{array}{c}506.90 \\
\text { (the least } \\
\text { health benefiting) }\end{array}$ \\
\hline
\end{tabular}




\section{Results}

Results show that among the selected alternative locations for pedestrian bridges, the best ranked is option. The differences among the alternatives are not substantial and vary in 12-20 per cent. The best alternative collects around 70 per cent of the best possible score. The worst alternative is $a_{5}$, and it collects around 55 per cent of the best possible score.

All used MCDM gave similar results (Table 5).

Table 5. Process and results of the problem solutions Initial decision matrix

\begin{tabular}{ccccccc}
\hline \multirow{2}{*}{ Alternatives } & \multicolumn{7}{c}{ Attributes } \\
\cline { 2 - 7 } & Usage & Connectivity & Cost-Effectiveness & Image & Road Safety & Health \\
& $\boldsymbol{x}_{\mathbf{1}}$ & $\boldsymbol{x}_{\mathbf{2}}$ & $\boldsymbol{m} \mathbf{\boldsymbol { x } _ { 3 }}$ & $\boldsymbol{x}_{\mathbf{4}}$ & $\boldsymbol{x}_{\mathbf{5}}$ & $\boldsymbol{x}_{\mathbf{6}}$ \\
\hline Optimum & $\max$ & $\mathbf{m a x}$ & $\min$ & $\max$ & $\max$ & $\max$ \\
\hline Weights, $\boldsymbol{w}$ & $\mathbf{0 . 2 1 2}$ & $\mathbf{0 . 2 4 4}$ & $\mathbf{0 . 2 0 0}$ & $\mathbf{0 . 1 7 2}$ & $\mathbf{0 . 0 8 2}$ & $\mathbf{0 . 0 9 0}$ \\
\hline$a_{1}$ & 9.7 & 405 & 3.53 & 247 & 2.0 & 13.9 \\
$a_{2}$ & 10.2 & 429 & 3.53 & 247 & 2.5 & 9.3 \\
$a_{3}$ & 8.6 & 404 & 3.38 & 495 & 2.0 & 16.2 \\
$a_{4}$ & 9.8 & 320 & 3.38 & 246 & 2.3 & 7.8 \\
$a_{5}$ & 7.9 & 327 & 3.53 & 247 & 2.2 & 13.8 \\
\hline
\end{tabular}

The method of Evaluation Based on Distance from Average Solution (EDAS)

\begin{tabular}{|c|c|c|c|c|c|c|}
\hline \multirow{3}{*}{ Alternatives } & \multicolumn{6}{|c|}{ Attributes } \\
\hline & Usage & Connectivity & Cost-Effectiveness & Image & Road Safety & Health \\
\hline & $x_{1}$ & $x_{2}$ & $x_{3}$ & $x_{4}$ & $x_{5}$ & $x_{6}$ \\
\hline Optimum & $\max$ & $\max$ & $\min$ & $\max$ & $\max$ & $\max$ \\
\hline$a_{1}$ & 9.7 & 405 & 3.53 & 247 & 2.0 & 13.9 \\
\hline$a_{2}$ & 10.2 & 429 & 3.53 & 247 & 2.5 & 9.3 \\
\hline$a_{3}$ & 8.6 & 404 & 3.38 & 495 & 2.0 & 16.2 \\
\hline$a_{4}$ & 9.8 & 320 & 3.38 & 246 & 2.3 & 7.8 \\
\hline$a_{5}$ & 7.9 & 327 & 3.53 & 247 & 2.2 & 13.8 \\
\hline$a_{6}$ & 12.2 & 515 & 2.82 & 594 & 9.0 & 19.4 \\
\hline $\begin{array}{c}\text { Arithmetic } \\
\text { mean }\end{array}$ & 9.7 & 400 & 3.36 & 346 & 3.3 & 13.4 \\
\hline
\end{tabular}


Positive distance from the solution average

\begin{tabular}{|c|c|c|c|c|c|c|c|c|}
\hline \multirow{2}{*}{ 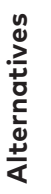 } & \multicolumn{6}{|c|}{ Attributes } & \multirow{3}{*}{$S P^{*}$} & \multirow{3}{*}{$N S P^{* *}$} \\
\hline & $\begin{array}{c}\text { Usage } \\
x_{1}\end{array}$ & $\begin{array}{c}\text { Connectivity } \\
x_{2}\end{array}$ & $\begin{array}{c}\text { Cost- } \\
\text { Effectiveness } \\
x_{3}\end{array}$ & $\begin{array}{c}\text { Image } \\
x_{4}\end{array}$ & $\begin{array}{c}\text { Road } \\
\text { Safety } \\
x_{5}\end{array}$ & $\begin{array}{c}\text { Health } \\
x_{6}\end{array}$ & & \\
\hline $\begin{array}{l}\frac{\varepsilon}{\partial} \\
\frac{\varepsilon}{2} \\
\text { on }\end{array}$ & $\max$ & $\max$ & $\min$ & $\max$ & $\max$ & $\max$ & & \\
\hline$a_{1}$ & -0.004 & 0.013 & -0.050 & -0.286 & -0.400 & 0.037 & -0.087 & -0.188 \\
\hline$a_{2}$ & 0.047 & 0.073 & -0.050 & -0.286 & -0.250 & -0.306 & -0.080 & -0.173 \\
\hline$a_{3}$ & -0.117 & 0.010 & -0.006 & 0.431 & -0.400 & 0.208 & 0.037 & 0.079 \\
\hline$a_{4}$ & 0.006 & -0.200 & -0.006 & -0.289 & -0.310 & -0.418 & -0.161 & -0.351 \\
\hline$a_{5}$ & -0.189 & -0.182 & -0.050 & -0.286 & -0.340 & 0.029 & -0.169 & -0.367 \\
\hline \multirow[t]{2}{*}{$a_{6}$} & 0.257 & 0.287 & 0.162 & 0.717 & 1.700 & 0.450 & 0.460 & 1.000 \\
\hline & & & & & & $\max$ & 0.460 & \\
\hline
\end{tabular}

Note: ${ }^{\star} S P$ is the weighted sum of the positive distance from average; ${ }^{\star \star} N S P$ is the normalised values of the weighted sum of the positive distance from average.

Negative distance from the solution average and results of the solutions

\begin{tabular}{|c|c|c|c|c|c|c|c|c|c|c|}
\hline \multirow{2}{*}{ 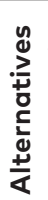 } & \multicolumn{6}{|c|}{ Attributes } & \multirow[b]{3}{*}{ 兌 } & \multirow[b]{3}{*}{$\sum_{k}^{*}$} & \multirow[b]{3}{*}{\begin{tabular}{l}
$*$ \\
$*$ \\
$*$ \\
\hdashline
\end{tabular}} & \multirow[b]{3}{*}{ 壬 } \\
\hline & $\begin{array}{c}\text { Usage } \\
x_{1}\end{array}$ & $\begin{array}{c}\text { Connectivity } \\
x_{2}\end{array}$ & $\begin{array}{c}\text { Cost- } \\
\text { Effectiveness } \\
x_{3}\end{array}$ & $\begin{array}{c}\text { Image } \\
x_{4}\end{array}$ & $\begin{array}{c}\text { Road } \\
\text { Safety } \\
x_{5}\end{array}$ & $\begin{array}{c}\text { Health } \\
\qquad x_{6}\end{array}$ & & & & \\
\hline 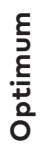 & $\max$ & $\max$ & $\min$ & $\max$ & $\max$ & $\max$ & & & & \\
\hline$a_{1}$ & 0.004 & -0.013 & 0.050 & 0.286 & 0.400 & -0.037 & 0.038 & 0.488 & 0.150 & 3 \\
\hline$a_{2}$ & -0.047 & -0.073 & 0.050 & 0.286 & 0.250 & 0.306 & 0.031 & 0.529 & 0.178 & 2 \\
\hline$a_{3}$ & 0.117 & -0.010 & 0.006 & -0.431 & 0.400 & -0.208 & -0.133 & 1.216 & 0.648 & 1 \\
\hline$a_{4}$ & -0.006 & 0.200 & 0.006 & 0.289 & 0.310 & 0.418 & 0.113 & 0.046 & -0.153 & 4 \\
\hline$a_{5}$ & 0.189 & 0.182 & 0.050 & 0.286 & 0.340 & -0.029 & 0.121 & 0.000 & -0.184 & 5 \\
\hline$a_{6}$ & -0.257 & -0.287 & -0.162 & -0.717 & -1.700 & -0.450 & -0.171 & 3.721 & 2.361 & 0 \\
\hline & & & & & & $\max$ & 0.121 & & & \\
\hline
\end{tabular}

Note: ${ }^{*} S P$ is the weighted sum of the positive distance from average; ${ }^{* *} N S N$ is the normalised values of the weighted sum of the negative distance from average for all alternatives; ${ }^{* * *} A S$ is the appraisal score. 
Additive Ratio Assessment (ARAS) method

\begin{tabular}{|c|c|c|c|c|c|c|}
\hline \multirow{3}{*}{ Alternatives } & \multicolumn{6}{|c|}{ Attributes } \\
\hline & Usage & Connectivity & Cost-Effectiveness & Image & Road Safety & Health \\
\hline & $x_{1}$ & $x_{2}$ & $x_{3}$ & $x_{4}$ & $x_{5}$ & $x_{6}$ \\
\hline Optimum & $\max$ & $\max$ & $\min$ & $\max$ & $\max$ & $\max$ \\
\hline Weights, w & 0.212 & 0.244 & 0.200 & 0.172 & 0.082 & 0.090 \\
\hline$a_{1}$ & 9.7 & 405 & 3.53 & 247 & 2.0 & 13.9 \\
\hline$a_{2}$ & 10.2 & 429 & 3.53 & 247 & 2.5 & 9.3 \\
\hline$a_{3}$ & 8.6 & 404 & 3.38 & 495 & 2.0 & 16.2 \\
\hline$a_{4}$ & 9.8 & 320 & 3.38 & 246 & 2.3 & 7.8 \\
\hline$a_{5}$ & 7.9 & 327 & 3.53 & 247 & 2.2 & 13.8 \\
\hline$a_{0}$ & 12.2 & 515 & 2.82 & 594 & 9.0 & 19.4 \\
\hline$\Sigma$ & 58.7 & 2400 & 20.40 & 2076 & 20.1 & 80.5 \\
\hline
\end{tabular}

Normalised matrix of the Additive Ratio Assessment (ARAS) method

\begin{tabular}{|c|c|c|c|c|c|c|}
\hline \multirow{3}{*}{ Alternatives } & \multicolumn{6}{|c|}{ Attributes } \\
\hline & Usage & Connectivity & Cost-Effectiveness & Image & Road Safety & Health \\
\hline & $x_{1}$ & $x_{2}$ & $x_{3}$ & $x_{4}$ & $x_{5}$ & $x_{6}$ \\
\hline Weights, w & 0.212 & 0.244 & 0.200 & 0.172 & 0.082 & 0.090 \\
\hline$a_{1}$ & 0.165 & 0.169 & 0.142 & 0.119 & 0.100 & 0.173 \\
\hline$a_{2}$ & 0.174 & 0.179 & 0.142 & 0.119 & 0.124 & 0.115 \\
\hline$a_{3}$ & 0.147 & 0.168 & 0.148 & 0.238 & 0.100 & 0.201 \\
\hline$a_{4}$ & 0.167 & 0.133 & 0.148 & 0.118 & 0.115 & 0.097 \\
\hline$a_{5}$ & 0.135 & 0.136 & 0.142 & 0.119 & 0.110 & 0.171 \\
\hline$a_{\circ}$ & 0.209 & 0.214 & 0.178 & 0.286 & 0.448 & 0.241 \\
\hline
\end{tabular}

Normalised and weighted matrix and solution results of the Additive Ratio Assessment (ARAS) method

\begin{tabular}{|c|c|c|c|c|c|c|c|c|c|}
\hline \multirow[b]{2}{*}{ 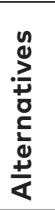 } & \multicolumn{6}{|c|}{ Attributes } & \multirow[b]{2}{*}{$K^{*}$} & \multirow[b]{2}{*}{$N^{* *}$} & \multirow[b]{2}{*}{ Rank } \\
\hline & $\begin{array}{c}\text { Usage } \\
x_{1}\end{array}$ & $\begin{array}{c}\text { Connectivity } \\
\qquad x_{2}\end{array}$ & $\begin{array}{c}\text { Cost- } \\
\text { Effectiveness } \\
x_{3}\end{array}$ & $\begin{array}{c}\text { Image } \\
x_{4}\end{array}$ & $\begin{array}{c}\text { Road } \\
\text { Safety } \\
x_{5}\end{array}$ & $\begin{array}{l}\text { Health } \\
\qquad x_{6}\end{array}$ & & & \\
\hline$a_{1}$ & 0.035 & 0.041 & 0.028 & 0.020 & 0.008 & 0.016 & 0.149 & 0.620 & 3 \\
\hline$a_{2}$ & 0.037 & 0.044 & 0.028 & 0.020 & 0.010 & 0.010 & 0.150 & 0.625 & 2 \\
\hline$a_{3}$ & 0.031 & 0.041 & 0.030 & 0.041 & 0.008 & 0.018 & 0.169 & 0.705 & 1 \\
\hline$a_{4}$ & 0.035 & 0.033 & 0.030 & 0.020 & 0.009 & 0.009 & 0.136 & 0.567 & 4 \\
\hline$a_{5}$ & 0.029 & 0.033 & 0.028 & 0.020 & 0.009 & 0.015 & 0.135 & 0.563 & 5 \\
\hline$a_{0}$ & 0.044 & 0.052 & 0.036 & 0.049 & 0.037 & 0.022 & 0.240 & 1.000 & 0 \\
\hline
\end{tabular}

Note: ${ }^{*} K$ is value of the multi-attribute utility function of choice; ${ }^{*} N$ represents utility degree of an option (utility compared with the optimal). 
Normalised and exponentially weighted matrix and solution results of the Multiplicative Exponential Weighting (MEW) method

\begin{tabular}{|c|c|c|c|c|c|c|c|c|c|}
\hline \multirow[b]{2}{*}{ 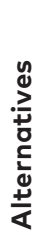 } & \multicolumn{6}{|c|}{ Attributes } & \multirow[b]{2}{*}{$K^{*}$} & \multirow[b]{2}{*}{$N^{* *}$} & \multirow[b]{2}{*}{ Rank } \\
\hline & $\begin{array}{c}\text { Usage } \\
x_{1}\end{array}$ & $\begin{array}{c}\text { Connectivity } \\
\qquad x_{2}\end{array}$ & $\begin{array}{c}\text { Cost- } \\
\text { Effectiveness } \\
x_{3}\end{array}$ & $\begin{array}{c}\text { Image } \\
x_{4}\end{array}$ & $\begin{array}{c}\text { Road } \\
\text { Safety } \\
x_{5}\end{array}$ & $\begin{array}{c}\text { Health } \\
\qquad x_{6}\end{array}$ & & & \\
\hline$a_{1}$ & 0.683 & 0.648 & 0.677 & 0.693 & 0.828 & 0.854 & 0.147 & 0.633 & 3 \\
\hline$a_{2}$ & 0.690 & 0.657 & 0.677 & 0.693 & 0.843 & 0.823 & 0.148 & 0.637 & 2 \\
\hline$a_{3}$ & 0.666 & 0.647 & 0.683 & 0.781 & 0.828 & 0.866 & 0.165 & 0.711 & 1 \\
\hline$a_{4}$ & 0.684 & 0.612 & 0.683 & 0.693 & 0.837 & 0.810 & 0.134 & 0.580 & 4 \\
\hline$a_{5}$ & 0.654 & 0.615 & 0.677 & 0.693 & 0.834 & 0.853 & 0.134 & 0.579 & 5 \\
\hline$a_{0}$ & 0.717 & 0.687 & 0.708 & 0.806 & 0.936 & 0.880 & 0.232 & 1.000 & 0 \\
\hline
\end{tabular}

Note: ${ }^{*} K$ is value of the multi-attribute utility function of choice; ${ }^{* \star} N$ represents utility degree of an option (utility compared with the optimal).

\section{Conclusions}

The following aspects summarise the main advantages that MultiCriteria Decision-Making provides in decision making:

- the possibility to analyse complex problems;

- the opportunity to aggregate both quantitative and qualitative criteria in the evaluation process;

- the potential of competent evidence of decisions;

- the chance for decision-maker to participate actively in the decision-making process; and

- the application of flexible scientific methods in the decisionmaking process.

- the utility function value in the newly proposed model determines the priorities of alternatives. Consequently, it is convenient to evaluate and rank decision alternatives using this model.

A comparison of the variant, which is analysed, with the ideally best one determines the degree of the alternative utility. The case study shows that the ratio with an optimal alternative may be used in cases when it is seeking to rank choices and find ways of improving alternative projects.

Three Multi-Criteria Decision-Making methods were applied to rank the options. Alternatives, according to all used methods rank in the same way: $a_{3}>a_{2}>a_{1}>a_{4}>a_{5}$. 
It means that the most preferable is alternative $a_{3}$, and it should be selected and implemented. Alternative $a_{2}$ is also promising, and if the budget is limited, it can be in preference before $a_{3}$.

The results show that in this situation, the alternatives $a_{4}$ and $a_{5}$ are worth of consideration to decline. Alternative $a_{1}$ must also be questioned and examined to find the solution for challenging river floods.

The proposed model can be modified and applied to solve different problems: to select, assess and rank constructions, technologies and other alternatives.

\section{REFERENCES}

Andersson, L., Silfwerbrand, J., Selander, A., \& Trägårdh, J. (2018). Continuous Preventive Bridge Maintenance of Swedish Municipalities-A Survey on Common Practice. Nordic Concrete Research, 58(1), 127-142. https://doi.org/10.2478/ncr-2018-0008

Antuchevičienė, J., Zavadskas, E. K., \& Turskis, Z. (2015). Evaluating and selecting a contractor for a construction company by using novel method for multi-attribute analysis: Weighted Aggregated Sum Product ASsessment with Grey values (WASPAS-G) method. Studies in Informatics and Control, 24(2), 141-150.

Arraes, P., Deyglun, L., Gardner, K., Osarczuk, S., \& Rajkarnikar, R. (2015). Tivoli Pedestrian Bridge. Splash Consulting Engineers. 92 p.

Balogun, T. B., Tomor, A., Lamond, J., Gouda, H., \& Booth, C. A. (2019, March). Sustainability of bridge maintenance. In Proceedings of the Institution of Civil Engineers-Bridge Engineering (Vol. 172, No. 1, pp. 54-64). Thomas Telford Ltd. https://doi.org/10.1680/jbren.15.00027

Bushell, M. A., Poole, B. W., Zegeer, C. V., \& Rodriguez, D. A. (2013). Costs for pedestrian and bicyclist infrastructure improvements. University of North Carolina Highway Safety Research Center, University of North Carolina, Chapel Hill, 45.

Congiu, T., Sotgiu, G., Castiglia, P., Azara, A., Piana, A., Saderi, L., \& Dettori, M. (2019). Built environment features and pedestrian accidents: An Italian retrospective study. Sustainability, 11(4), 1064. https://doi.org/10.3390/su11041064

Cooper, C. H. (2018). Predictive spatial network analysis for high-resolution transport modeling, applied to cyclist flows, mode choice, and targeting investment. International journal of sustainable transportation, 12(10), 714-724. https://doi.org/10.1080/15568318.2018.1432730

Fang, X., Li, X., Yu, T., Guo, Z., \& Ma, T. (2019). Grey Markov model prediction method for regular pedestrian movement trend. In Proceedings of 2018 Chinese intelligent systems conference (pp. 575-584). Springer, Singapore. https://doi.org/10.1007/978-981-13-2288-4_55

Fujino, Y. (2018, July). Bridge maintenance, renovation and management-Research and Development of governmental program in 
Japan. In Maintenance, Safety, Risk, Management and Life-Cycle Performance of Bridges: Proceedings of the Ninth International Conference on Bridge Maintenance, Safety and Management (IABMAS 2018), 9-13 July 2018, Melbourne, Australia (p. 2). CRC Press.

García-Segura, T., Penadés-Plà, V., \& Yepes, V. (2018). Sustainable bridge design by metamodel-assisted multi-objective optimisation and decision-making under uncertainty. Journal of Cleaner Production, 202, 904-915. https://doi.org/10.1016/j.jclepro.2018.08.177

Gongora, D. A., Baquero, J. J. D., Franco, J. F., \& Mura, I. (2018, December). Simulation to Predict Cyclists' Exposure to Air Pollution Along Bikeways. In 2018 Winter Simulation Conference (WSC) (pp. 2387-2398). IEEE. https://doi.org/10.1109/WSC.2018.8632358

Gössling, S., Humpe, A., Litman, T., \& Metzler, D. (2019). Effects of perceived traffic risks, noise, and exhaust smells on bicyclist behaviour: An economic evaluation. Sustainability, 11(2), 408. https://doi.org/10.3390/su11020408

Hartmann, M., Ferrara, A., \& Watzenig, D. (2018, September). Data-based reachability analysis for movement prediction of pedestrians and motion planning. In 2018 IEEE International Conference on Vehicular Electronics and Safety (ICVES) (pp. 1-7). IEEE. https://doi.org/10.1109/ICVES.2018.8519517

Hartmann, M., Stolz, M., \& Watzenig, D. (2018). Movement prediction hypotheses for pedestrians and trajectory planning for cooperative driving systems. $S A E$ International Journal of Connected and Automated Vehicles, 2(12-02-01-0002). https://doi.org/10.4271/12-02-01-0002

Hashemi, H., Mousavi, S. M., Zavadskas, E. K., Chalekaee, A., \& Turskis, Z. (2018). A new group decision model based on grey-intuitionistic fuzzy-ELECTRE and VIKOR for contractor assessment problem. Sustainability, 10(5), 1635. https://doi.org/10.3390/su10051635

Jack, D., Pantaleo, N., Smith, C., Yang, Q., Thornburg, J., Kinney, P., \& Chillrud, S. (2018, September). Using Spatially Resolved Pollution Data to Plan Bicycle Infrastructure. In ISEE Conference Abstracts (Vol. 2018, No. 1).

Jereb, B., Batkovič, T., Herman, L., Šipek, G., Kovše, Š., Gregorič, A., \& Močnik, G. (2018). Exposure to black carbon during bicycle commuting-alternative route selection. Atmosphere, 9(1), 21. https://doi.org/10.3390/atmos9010021

Jia, J., Ibrahim, M., Hadi, M., Orabi, W., Ali, M., \& Xiao, Y. (2016, January). Estimation of the total cost of bridge construction for use in accelerated bridge construction selection decisions. In Transportation Research Board 95th Annual Meeting (No. 16-6305, p. 17).

Jin, J. (2018). Riverfront redevelopment in a medium-sized city: taking White River sites in downtown Indianapolis as an example.

Juodagalvienė, B., Turskis, Z., Šaparauskas, J., \& Endriukaitytė, A. (2017). Integrated multi-criteria evaluation of house's plan shape based on the EDAS and SWARA methods. Engineering Structures and Technologies, 9(3), 117-125. https://doi.org/10.3846/2029882X.2017.1347528

Kajosaari, A., Hasanzadeh, K., \& Kyttä, M. (2019). Residential dissonance and walking for transport. Journal of transport geography, 74, 134-144.

https://doi.org/10.1016/j.jtrangeo.2018.11.012 
Keršulienè, V., Zavadskas, E. K., \& Turskis, Z. (2010). Selection of rational dispute resolution method by applying new step-wise weight assessment ratio analysis (SWARA). Journal of business economics and management, 11(2), 243-258. https://doi.org/10.3846/jbem.2010.12

Keshavarz Ghorabaee, M., Zavadskas, E. K., Olfat, L., \& Turskis, Z. (2015). Multi-criteria inventory classification using a new method of evaluation based on distance from average solution (EDAS). Informatica, 26(3), 435-451. https://doi.org/10.15388/Informatica.2015.57

Koohsari, M. J., Oka, K., Owen, N., \& Sugiyama, T. (2019). Natural movement: A space syntax theory linking urban form and function with walking for transport. Health \& place, 58, 102072.

https://doi.org/10.1016/j.healthplace.2019.01.002

Li, C., Chi, G., \& Jackson, R. (2018). Neighbourhood built environment and walking behaviours: Evidence from the rural American South. Indoor and built environment, 27(7), 938-952.

https://doi.org/10.1177/1420326x17695858

Luo, J., Boriboonsomsin, K., \& Barth, M. (2020). Consideration of exposure to traffic-related air pollution in bicycle route planning. Journal of Transport \& Health, 16, 100792. https://doi.org/10.1016/j.jth.2019.100792

Marshall, S., Gil, J., Kropf, K., Tomko, M., \& Figueiredo, L. (2018). Street network studies: from networks to models and their representations. Networks and Spatial Economics, 18(3), 735-749. https://doi.org/10.1007/s11067-018-9427-9

Minet, L., Stokes, J., Scott, J., Xu, J., Weichenthal, S., \& Hatzopoulou, M. (2018). Should traffic-related air pollution and noise be considered when designing urban bicycle networks? Transportation Research Part D: Transport and Environment, 65, 736-749. https://doi.org/10.1016/j.trd.2018.10.012

Mohtasham-Amiri, Z., Barge_Gol, I., Jafari-Shakib, H., \& Abedian, P. (2018). PW 0677 Factors influencing the use of pedestrian bridges. Injury Prevention, 24(Suppl 2), A56. https://doi.org/10.1136/injury prevention-2018-safety.152

Nowacka-Rejzner, U. (2019, February). River and Riverside Areas-in the Context of Shaping the Urban Space-Case Study. In IOP Conference Series: Materials Science and Engineering (Vol. 471, No. 11, p. 112088). IOP Publishing. https://doi.org/10.1088/1757-899X/471/11/112088

Oliveira, R., Figueiredo, A., Vicente, R., \& Almeida, R. M. (2018). Multi-objective optimisation of the energy performance of lightweight constructions combining evolutionary algorithms and life cycle cost. Energies, 11(7), 1863. https://doi.org/10.3390/en11071863

Otero, I., Nieuwenhuijsen, M. J., \& Rojas-Rueda, D. (2018). Health impacts of bike sharing systems in Europe. Environment international, 115, 387-394. https://doi.org/10.1016/j.envint.2018.04.014

Pafka, E., Dovey, K., \& Aschwanden, G. D. (2018). Limits of space syntax for urban design: Axiality, scale and sinuosity. Environment and Planning B: Urban Analytics and City Science, 2399808318786512. https://doi.org/10.1177/2399808318786512 
Parthasarathi, P., \& Levinson, D. (2018). Network structure and the journey to work: An intra-metropolitan analysis. Transportation Research Part A: Policy and Practice, 118, 292-304. https://doi.org/10.1016/j.tra.2018.09.008

Particke, F., Hiller, M., Feist, C., \& Thielecke, J. (2018, April). Improvements in pedestrian movement prediction by considering multiple intentions in a multi-hypotheses filter. In 2018 IEEE/ION Position, Location and Navigation Symposium (PLANS) (pp. 209-212). IEEE. https://doi.org/10.1109/PLANS.2018.8373383

Pellegrini, L., Ribó, R., Jordan, J., \& Sobrino, J. (2017). Sustainable Pedestrian Bridge using Advanced Materials (SUPERBAM).

Qiu, Z., Song, J., Hao, C., Li, X., \& Gao, H. O. (2018). Investigating traffic-related PM exposure on and under pedestrian bridges: A case study in Xi'an, China. Atmospheric Pollution Research, 9(5), 877-886. https://doi.org/10.1016/j.apr.2018.02.009

Ridel, D., Rehder, E., Lauer, M., Stiller, C., \& Wolf, D. (2018, November). A literature review on the prediction of pedestrian behavior in urban scenarios. In 2018 21st International Conference on Intelligent Transportation Systems (ITSC) (pp. 3105-3112). IEEE. https://doi.org/10.1109/ITSC.2018.8569415

Ruzgys, A., Volvačiovas, R., Ignatavičius, Č., \& Turskis, Z. (2014). Integrated evaluation of external wall insulation in residential buildings using SWARA-TODIM MCDM method. Journal of Civil Engineering and Management, 20(1), 103-110. https://doi.org/10.3846/13923730.2013.843585

Saaty, T. L. (1977). A scaling method for priorities in hierarchical structures. Journal of mathematical psychology, 15(3), 234-281. https://doi.org/10.1016/0022-2496(77)90033-5

Saaty, T. L. (1990). Multicriteria decision making: the analytic hierarchy process: planning, priority setting resource allocation.

Šaparauskas, J., Zavadskas, E. K., \& Turskis, Z. (2011). Selection of facade's alternatives of commercial and public buildings based on multiple criteria. International Journal of Strategic Property Management, 15(2), 189-203. https://doi.org/10.3846/1648715X.2011.586532

Seltenrich, N. (2018). Another Potential Risk Factor for ALS: Exposure to Traffic-Related Air Pollutants. Environmental health perspectives, 126(2), 024004. https://doi.org/10.1289/EHP2882

Sender, J., \& Maslanko, W. (2018). Natural Values of the Urban River Valley and the Possibilities of its Development-Bystrzyca River Valley Study Case (Poland). Transylvanian Review of Systematical and Ecological Research, 20(2), 85-102.

Sharmin, S., \& Kamruzzaman, M. (2018). Meta-analysis of the relationships between space syntax measures and pedestrian movement. Transport Reviews, 38(4), 524-550. https://doi.org/10.1080/01441647.2017.1365101

Shekarrizfard, M., Valois, M. F., Weichenthal, S., Goldberg, M. S., Fallah-Shorshani, M., Cavellin, L. D., \& Hatzopoulou, M. (2018). Investigating the effects of multiple exposure measures to traffic-related air pollution on the risk of breast and prostate cancer. Journal of Transport \& Health, 11, 34-46.

https://doi.org/10.1016/j.jth.2018.09.006 
Sivilevičius, H., Zavadskas, E. K., \& Turskis, Z. (2008). Quality attributes and complex assessment methodology of the asphalt mixing plant. Baltic Journal of Road \& Bridge Engineering (Baltic Journal of Road \& Bridge Engineering), 3(3). https://doi.org/10.3846/1822-427x.2008.3.161-166

Štreimikienè, D., Šliogerienè, J., \& Turskis, Z. (2016). Multi-criteria analysis of electricity generation technologies in Lithuania. Renewable Energy, 85, 148-156. https://doi.org/10.1016/j.renene.2015.06.032

Suzuki, S. (2018). Comparative Analysis of Human Movement Prediction: Space Syntax and Inverse Reinforcement Learning. arXiv preprint arXiv:1801.00464.

Turskis, Z., \& Juodagalvienè, B. (2016). A novel hybrid multi-criteria decision-making model to assess a stairs shape for dwelling houses. Journal of Civil Engineering and Management, 22(8), 1078-1087. https://doi.org/10.3846/13923730.2016.1259179

Turskis, Z., Dzitac, S., Stankiuvienè, A., \& Šukys, R. (2019). A Fuzzy Group Decision-making Model for Determining the Most Influential Persons in the Sustainable Prevention of Accidents in the Construction SMEs. International Journal of Computers, Communications \& Control, 14(1). https://doi.org/10.15837/ijccc.2019.1.3364

Vert, C., Nieuwenhuijsen, M., Gascon, M., Grellier, J., Fleming, L. E., White, M. P., \& Rojas-Rueda, D. (2019). Health benefits of physical activity related to an urban Riverside regeneration. International journal of environmental research and public health, 16(3), 462. https://doi.org/10.3390/ijerph16030462

Wu, J., Ruenz, J., \& Althoff, M. (2018, June). Probabilistic map-based pedestrian motion prediction taking traffic participants into consideration. In 2018 IEEE Intelligent Vehicles Symposium (IV) (pp. 1285-1292). IEEE. https://doi.org/10.1109/IVS.2018.8500562

Xie, H. B., Wu, W. J., \& Wang, Y. F. (2018). Life-time reliability based optimisation of bridge maintenance strategy considering LCA and LCC. Journal of cleaner production, 176, 36-45. https://doi.org/10.1016/j.jclepro.2017.12.123

Zalakeviciute, R., Buenaño, A., Sannino, D., \& Rybarczyk, Y. (2018). Urban air pollution mapping and traffic intensity: active transport application. In Air Pollution-Monitoring, Quantification and Removal of Gases and Particles. IntechOpen. https://doi.org/10.5772/intechopen.79570

Zavadskas, E. K., \& Turskis, Z. (2010). A new additive ratio assessment (ARAS) method in multicriteria decision-making. Technological and Economic Development of Economy, 16(2), 159-172. https://doi.org/10.3846/tede.2010.10

Zavadskas, E. K, Antucheviciene, J., Adeli, H., \& Turskis, Z. (2016). Hybrid multiple criteria decision making methods: A review of applications in engineering. Scientia Iranica, 23(1), 1-20.

https://doi.org/10.24200/sci.2016.2093

Zavadskas, E. K., Govindan, K., Antucheviciene, J., \& Turskis, Z. (2016). Hybrid multiple criteria decision-making methods: A review of applications for sustainability issues. Economic research-Ekonomska istraživanja, 29(1), 857-887. https://doi.org/10.1080/1331677X.2016.1237302

Zavadskas, E. K., Kaklauskas, A., Turskis, Z., \& Kalibatas, D. (2009). An approach to multi-attribute assessment of indoor environment before and after 
refurbishment of dwellings. Journal of Environmental Engineering and Landscape Management, 17(1), 5-11. https://doi.org/10.3846/1648-6897.2009.17.5-11

Zavadskas, E. K., Liias, R., \& Turskis, Z. (2008). Multi-attribute decision-making methods for assessment of quality in bridges and road construction: state-of-the-art surveys. The baltic journal of road and bridge engineering, 3(3), 152-160. https://doi.org/10.3846/1822-427X.2008.3.152-160

Zavadskas, E. K., Mardani, A., Turskis, Z., Jusoh, A., \& Nor, K. M. (2016). Development of TOPSIS method to solve complicated decision-making problems-An overview on developments from 2000 to 2015. International Journal of Information Technology \& Decision Making, 15(03), 645-682. https://doi.org/10.1142/S0219622016300019

Zavadskas, E. K., Turskis, Z., \& Antucheviciene, J. (2015). Selecting a contractor by using a novel method for multiple attribute analysis: Weighted Aggregated Sum Product Assessment with grey values (WASPAS-G). Studies in Informatics and Control, 24(2), 141-150. https://doi.org/10.24846/v24i2y201502

Zavadskas, E. K., Turskis, Z., \& Bagočius, V. (2015). Multi-criteria selection of a deep-water port in the Eastern Baltic Sea. Applied Soft Computing, 26, 180-192. https://doi.org/10.1016/j.asoc.2014.09.019

Zavadskas, E. K., Turskis, Z., \& Kildienė, S. (2014). State of art surveys of overviews on MCDM/MADM methods. Technological and Economic Development of Economy, 20(1), 165-179.

https://doi.org/10.3846/20294913.2014.892037

Zavadskas, K. E., Antucheviciene, J., Adeli, H., \& Turskis, Z. (2016). Hybrid multiple criteria decision making methods: A review of applications in engineering. Scientia Iranica, 23(1), 1-20.

https:// doi.org/10.24200/sci.2016.2093

Zolfani, S. H., Zavadskas, E. K., \& Turskis, Z. (2013). Design of products with both International and Local perspectives based on Yin-Yang balance theory and SWARA method. Economic research-Ekonomska istraživanja, 26(2), 153-166. https://doi.org/10.1080/1331677X.2013.11517613 